\title{
Pattern Analysis Of Purely Dermal Cutaneous Mesenchymal Tumours Presenting As Superficial Palpable Growth
}

\author{
Swati Patki* and Madhu Chaturvedi \\ Dept. of Pathology, LTMMC and LTMGH, Sion, Mumbai (India)
}

\begin{abstract}
Background: Cutaneous mesenchymaltumours are relatively rare except for a small number of lesions that are very common.Benign cuteneous soft tissue tumors outnumber malignant tumors by a wide margin.Malignant cutaneous soft tissue tumors, on the other hand, ultimately come to medical attention. Soft tissue sarcomas, compared with carcinomas and other neoplasms, are relatively rare and constitute fewer than $1 \%$ of all cancers .A systematic approach can help achieve a definitive diagnosis or limit a differential diagnosis and prevents over-treatment or under-treatment.This study will focus on primary cutaneous (particularly dermal) soft tissue tumours that can be part of syndrome e.g. neurofibromas associated with von Recklinghausen's disease or benign tumors that simulate malignancies and are often misdiagnosed as such e.g. fibrous histiocytoma and low-grade malignant cutaneous soft tissue tumours that although rare are often associated with high morbidity and mortality.
\end{abstract}

Material and Methods: The present cross sectional analytical study was conducted in department of Pathology of a tertiary care hospital over a period of five years. All the incision biopsy and resection specimens received in the department of surgical pathology suggestive of cutaneous soft tissue tumours (purely dermal) as per clinical and morphological details.

Result: The data was analyzed using rates, ratios and percentages. Association between incidence of cutaneous soft tissue tumours\& various demographic parameters like age, sex, were calculated.

Conclusion: Pathologists play an important role in reaching to accurate morphological diagnosis with the aid of IHC to prevent any uncertainty due to indistinct clinical features

Keywords: Cutaneous, Mesenchymal

\section{Introduction}

There are more than 100 soft tissue tumours most of which can involve the skin either primarily or by extension from deep soft tissues. However, cutaneous mesenchymal tumours (purely dermal) are relatively rare. Amongst cutaneous soft tissue tumours a small number of lesions are very common and easy to diagnose both on clinical and histological grounds, include dermatofibromas (fibrous histiocytomas), capillary and cavernous haemangiomas, lipomas and fibroepithelial polyps. Other relatively more infrequent tumours including glomus tumour, leiomyoma, angiosarcoma and Kaposi's sarcoma often have fairly typical features that allow clinical recognition. But many cutaneous soft tissue tumours display no distinctive clinical features and they are removed by dermatologists and surgeons without a specific clinical diagnosis other than that of cyst or lipoma. They rely on histopathologist for a definite diagnosis to understand the nature and prognosis of the lesion they have excised. The great majority of soft tissue tumours that involve the skin primarily are benign but they can pose serious problems in histological differential diagnosis and may mimic malignancy. Contrariwise, malignant or more commonly low-grade malignant tumours may focally mimic a benign process. A systematic approach can help achieve a definitive diagnosis or limit a differential diagnosis and prevents over-treatment or under-treatment.

The present study was undertaken to study clinical, morphological and demographic features of purely dermal cutaneous soft tissue tumours. ${ }^{[1,2,3]}$

\section{Materials and Methods}

Study Design: The present cross sectional analytical study was conducted in department of Pathology of a tertiary care hospital over a period of five years.

Inclusion Criteria: 1.) All the incision biopsy and resection specimens received in the department of surgical pathology suggestive of cutaneous soft tissue tumours (purely dermal) as per clinical and morphological details. And 2.) Any age group and gender.

Exclusion Criteria: Following tumours were excluded from the study:-

1. Melanocytic tumours

2. Epidermal tumours

3. Skin adnexal tumours 
Paraffin embedded tissue blocks of tumours diagnosed as cutaneous soft tissue tumours both benign \& malignant, were retrieved from surgical pathology section. The clinical details of patients were obtained from case files retrieved from medical records section of hospital. The new patients diagnosed with cutaneous soft tissue tumours were briefed about the nature of study \& written and informed consent was obtained. Thorough history was taken \& finding was recorded on predesigned \& pretested proforma. The biopsies \& resected surgical specimens were received at surgical pathology section in $10 \%$ formalin fixative. These specimens were subjected to meticulous inspection of external and cut surface. Gross findings were noted. The specimens were grossed and multiple representative bits from tumour, adjacent tissue, all surgical margins and any other relevant areas were submitted for processing. Biopsies were submitted entirely for processing.

Thin section 3-4mm thick was cut from the paraffin block. The slides prepared were routinely stained with H \& E \& evaluated for light microscopy. IHC staining was employed in few cases where a routine morphology \& histochemistry was unsuccessful in providing a definitive diagnosis.

Data obtained was coded and entered into Microsoft Excel spread sheet. The data was analyzed using rates, ratios and percentages. Association between incidence of cutaneous soft tissue tumours \& various demographic parameters like age, sex, were calculated. Percentages are considered as 1 for $100 . \mathrm{P}<=0.05$ is considered significant.

\section{Result}

Total number of tumours received, over a period of five years was 147.The cases studied were grouped as per WHO classification into adipocytic, fibrohistiocytic, fibroblastic, vascular, perivascular, nerve sheath tumours and tumours of uncertain differentiation and categorized as : benign, Intermediate, malignant. There were 17 tumour like lesions, of which 11 were keloid and 6 granuloma pyogenicum. Nature and type wise distribution of cutaneous mesenchymal tumours is shown in Table 1.

Benign tumors formed the largest group of 121 (82.3\%) cases.

The mean age for cases of cutaneous soft tissue tumours was 31.7 years with range being 0.3-75 years. Malignant tumors occurred more commonly in the elderly age group of $>50$ years and all benign tumors most commonly occurred in the age group of 20-30 years. The percentage of occurrence of cutaneous soft tissue tumors in different age groups was significant with $\mathrm{p}$-value being $<0.01$ by Fischer's exact test.

Male predominance was noted $(61.7 \%, 92)$. M: F ratio was 1.61:1. Sex wise distribution of various benign cutaneous soft tissue tumours was evaluated as follows:

\begin{tabular}{|c|c|c|c|c|c|c|c|}
\hline \multirow{2}{*}{\multicolumn{2}{|c|}{$\begin{array}{l}\text { Sex } \\
\text { BFH }\end{array}$}} & \multicolumn{5}{|c|}{ Benign specific } & \multirow{2}{*}{ Total } \\
\hline & & Haemangioma & Lipoma & Neurofibroma & Schwanoma & & \\
\hline \multirow{2}{*}{$\mathrm{F}$} & Count & 5 & 10 & 18 & 6 & 5 & 44 \\
\hline & $\%$ & 0.1 & 0.2 & 0.4 & 0.1 & 0.1 & 1.0 \\
\hline \multirow{2}{*}{ M } & Count & 5 & 26 & 29 & 8 & 7 & 75 \\
\hline & $\%$ & 0.1 & 0.3 & .4 & 0.1 & 0.1 & 1.0 \\
\hline \multirow{2}{*}{ Total } & Count & 10 & 36 & 47 & 14 & 12 & 119 \\
\hline & $\%$ & 0.1 & 0.3 & 0.4 & 0.1 & 0.1 & 1.0 \\
\hline
\end{tabular}

P Value: 0.64 by Fisher's exact test.

There was no difference in tumor distribution in both sexes in various benign cutaneous soft tissue tumors.

Most common site for benign tumors was head and neck region and that for malignant tumors was lower extremity. Site wise distribution of various benign cutaneous soft tissue tumors was analyzed as follows:

\begin{tabular}{|c|c|c|c|c|c|c|c|}
\hline \multirow{2}{*}{\multicolumn{2}{|c|}{$\begin{array}{l}\text { Site of lesion } \\
\text { BFH }\end{array}$}} & \multicolumn{5}{|c|}{ Benign specific } & \multirow{3}{*}{$\begin{array}{c}\text { Total } \\
1 \\
\end{array}$} \\
\hline & & \multirow{2}{*}{\begin{tabular}{|c|} 
Haemangioma \\
0 \\
\end{tabular}} & \multirow{2}{*}{$\begin{array}{c}\text { Lipoma } \\
1 \\
\end{array}$} & \multirow{2}{*}{\begin{tabular}{|c|} 
Neurofibroma \\
0 \\
\end{tabular}} & \multirow{2}{*}{$\begin{array}{c}\text { Schwanoma } \\
0 \\
\end{array}$} & \multirow[b]{2}{*}{0} & \\
\hline Scrotal ckin & Count & & & & & & \\
\hline SCIULAI SKIII & $\%$ & 0 & 1.0 & 0 & 0 & 0 & 1.0 \\
\hline \multirow{2}{*}{ Back } & Count & 2 & 3 & 10 & 4 & 1 & 20 \\
\hline & $\%$ & 0.1 & 0.2 & 0.5 & 0.2 & 0.1 & 1.0 \\
\hline \multirow{2}{*}{ Chest } & Count & 0 & 1 & 2 & 1 & 0 & 4 \\
\hline & $\%$ & 0 & 0.3 & 0.5 & 0.3 & 0 & 1.0 \\
\hline
\end{tabular}




\begin{tabular}{|c|c|c|c|c|c|c|c|}
\hline \multirow{2}{*}{\multicolumn{2}{|c|}{$\begin{array}{l}\text { Site of lesion } \\
\text { BFH }\end{array}$}} & \multicolumn{5}{|c|}{ Benign specific } & \multirow{3}{*}{$\begin{array}{r}\text { Total } \\
39 \\
\end{array}$} \\
\hline & & \multirow{2}{*}{$\begin{array}{c}\text { Haemangioma } \\
2 \\
\end{array}$} & \multirow{2}{*}{$\begin{array}{c}\text { Lipoma } \\
15 \\
\end{array}$} & \multirow{2}{*}{$\begin{array}{c}\text { Neurofibroma } \\
14\end{array}$} & \multirow{2}{*}{$\begin{array}{c}\text { Schwanoma } \\
4\end{array}$} & \multirow[b]{2}{*}{4} & \\
\hline Head and & Count & & & & & & \\
\hline neck & $\%$ & 0.1 & 0.4 & 0.4 & 0.1 & 0.1 & 1.0 \\
\hline \multirow{2}{*}{$\begin{array}{l}\text { Lower } \\
\text { extremity }\end{array}$} & Count & 2 & 8 & 10 & 1 & 4 & 25 \\
\hline & $\%$ & 0.1 & 0.3 & 0.4 & 0 & 0.2 & 1.0 \\
\hline \multirow{2}{*}{$\begin{array}{l}\text { Upper } \\
\text { extremity }\end{array}$} & Count & 4 & 8 & 10 & 3 & 3 & 28 \\
\hline & $\%$ & 0.1 & 0.3 & 0.4 & 0.1 & 0.1 & 1.0 \\
\hline \multirow{2}{*}{$\begin{array}{l}\text { All over the } \\
\text { body }\end{array}$} & Count & 0 & 0 & 1 & 1 & 0 & 2 \\
\hline & $\%$ & 0 & 0 & 0.5 & 0.5 & 0 & 1.0 \\
\hline \multirow{2}{*}{ Total } & Count & 10 & 36 & 47 & 14 & 12 & 119 \\
\hline & $\%$ & 0.1 & 0.3 & 0.4 & 0.1 & 0.1 & 1.0 \\
\hline
\end{tabular}

$P$ Value: 0.83 by Fisher's exact test.

Though $\mathrm{P}$ value was insignificant in tumor distribution over various sites in benign cutaneous soft tissue tumors, however, head and neck region showed commonly haemangioma followed by lipoma whereas extremities and back showed lipoma.

Rate of growth of the tumours were correlated with the behavior of the tumour. Tumours with growth duration of 0-6 months were considered to have rapid growth and tumours growing over a period of 7 months $-\geq 2$ years were considered as slow growing tumours.

Most of the tumours $(120,92.3 \%)$ were slow growing and were benign. Intermediate malignant and malignant tumours showed rapid growth.

Majority of cases presented as solitary growth (91.05\%). (fig. 1a,b,c)

Correlation of consistency and nature of growth was done as follows:

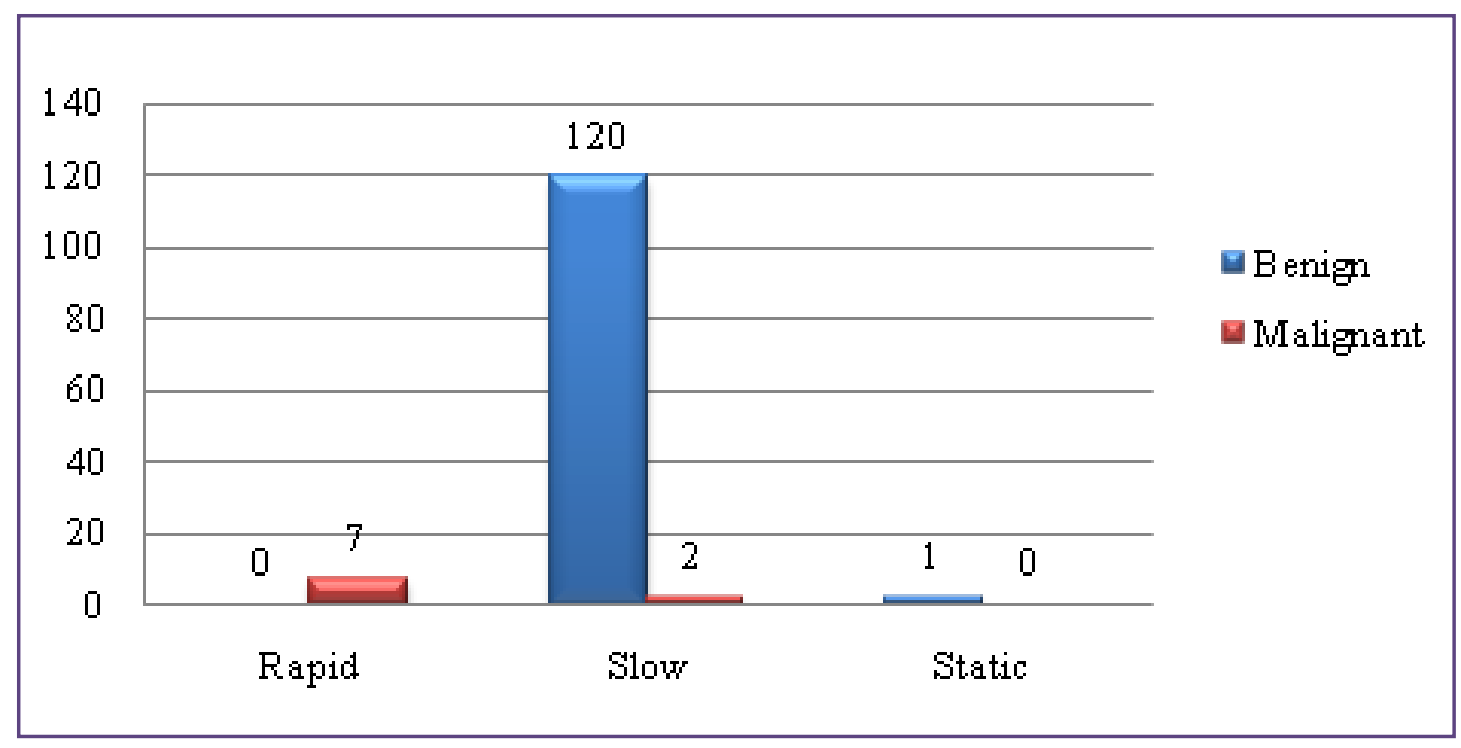

\begin{tabular}{|l|c|c|c|c|c|c|}
\hline \multirow{2}{*}{ Type of growth } & \multicolumn{3}{|c|}{ Frequency $(\mathrm{n}=147)$} & \multicolumn{3}{c|}{ Percent (\%) } \\
\hline & Benign $(\mathrm{n}=121)$ & Malignant $(\mathrm{n}=9)$ & Tumor like $(\mathrm{n}=17)$ & Benign (\%) & Malignant (\%) & Tumor like (\%) \\
\hline Cystic & 21 & 1 & 5 & 17.4 & 11.1 & 29.4 \\
\hline Solid & 100 & 8 & 12 & 82.6 & 88.9 & 70.6 \\
\hline Total & 121 & $\mathbf{9}$ & 17 & 100 & 100 & 100 \\
\hline
\end{tabular}


Majority of benign tumours $(82.6 \%)$, malignant tumours $(88.9 \%)$ and tumour like lesions $(70.6 \%)$ presented as solid growth.

In few cases definitive diagnosis could not be reached on morphology alone, so Immunohistochemistry was performed. (Table 2)

Cutaneous mesenchymal tumours in paediatric age group:

There were 27 cases $(18.4 \%)$ in the paediatric age group. Four were neonates, 15 child and 8 adolescents. The age range was from 4 months to 17 years. Mean age affected being 8 years. There were 18 males and 9 females. All were benign tumors except 3 cases with tumour like lesions (1 granuloma pyogenicum, 2 keloid). Most common benign tumor noted was capillary haemangioma (15 cases) in the head and neck region. Majority of haemangioma presented as cystic growth. Average duration of growth was 1 and half years (range since birth- 2 years). Besides this a lipoma, 3 benign fibrous histiocytoma, 4 neurofibroma, and a schwannoma was also noted in this age group.

Table 1: Nature and type wise distribution of skin connective tissue tumours $(n=, \%)$

\begin{tabular}{|c|c|c|c|}
\hline $\begin{array}{l}\text { Nature of tumour } \rightarrow \text { Type of } \\
\text { tumour } 130,100 \%\end{array}$ & $\begin{array}{l}\text { Benign } \\
121(82.3 \%)\end{array}$ & $\begin{array}{l}\text { Intermediate } \\
5(3.8 \%)\end{array}$ & $\begin{array}{l}\text { Malignant } \\
4(3.1 \%)\end{array}$ \\
\hline $\begin{array}{l}\text { Adipocytic tumours } \\
48(36.9 \%)\end{array}$ & $\begin{array}{l}\text { Lipoma } 39(30 \%) \\
\text { Angiolipoma } 2(1.5 \%) \\
\text { Fibrolipoma } 6(4.6 \%)\end{array}$ & $\begin{array}{l}\text { Well differentiated } \\
\text { liposarcoma } 1(0.8 \%)\end{array}$ & \\
\hline $\begin{array}{l}\text { Fibrohistiocytic tumours } \\
11(8.5 \%)\end{array}$ & $\begin{array}{l}\text { Benign fibrous histiocytoma } \\
9(6.9 \%)\end{array}$ & $\begin{array}{l}\text { Atypical fibrous histiocytoma } \\
1(0.8 \%)\end{array}$ & $\begin{array}{l}\text { Undifferentiated pleomorphic } \\
\text { sarcoma } 1(0.8 \%)\end{array}$ \\
\hline $\begin{array}{l}\text { Vascular tumors } \\
33(25.4 \%)\end{array}$ & $\begin{array}{l}\text { Capillary haemangioma } \\
27(20.8 \%) \\
\text { Cavernous haemangioma } \\
1(0.8 \%) \\
\text { AV haemangioma } \\
5(3.8 \%)\end{array}$ & & \\
\hline $\begin{array}{l}\text { Perivascular tumor } \\
1(0.8 \%)\end{array}$ & Glomus tumour1 (0.8\%) & & \\
\hline Fibroblastic tumour 6(4.6\%) & Fibroma $2(1.5 \%)$ & $\begin{array}{l}\text { Dermatofibrosarcoma } \\
\text { protuberance } 3(2.3 \%)\end{array}$ & Myxofibrosarcoma 1(0.8\%) \\
\hline $\begin{array}{l}\text { Nerve sheath tumour } \\
30(23.1 \%)\end{array}$ & $\begin{array}{l}\text { Dermal nerve sheath } \\
\text { myxoma } 2(1.5 \%) \\
\text { Neurofibroma } 13(10 \%) \\
\text { Schwannoma } 12(9.2 \%) \\
\text { Neuroma } 1(0.8 \%)\end{array}$ & & $\begin{array}{l}\text { Malignant nerve sheath } \\
\text { tumour } 2(1.5 \%)\end{array}$ \\
\hline $\begin{array}{l}\text { Tumour of uncertain } \\
\text { differentiation } 1(0.8 \%)\end{array}$ & $\begin{array}{l}\text { Cutaneous myoepithelioma } \\
1(0.8 \%)\end{array}$ & & \\
\hline
\end{tabular}

Table 2: IHC findings of cutaneous soft tissue tumours

\begin{tabular}{|l|l|l|}
\hline INITIAL DIAGNOSIS & IHC finding & FINAL DIAGNOSIS \\
\hline ?DFSP & CD34-positive,S-100-negative & DFSP \\
\hline Atypical fibrous histiocytoma & $\begin{array}{l}\text { CD68-positive,Ki 67-low index,SMA- } \\
\text { negative,CD34 -negative }\end{array}$ & BFH \\
\hline $\begin{array}{l}\text { Capillary lobular hemangioma to rule } \\
\text { out Kaposi sarcoma }\end{array}$ & HHV-8=negative & Capillary lobular hemangioma \\
\hline $\begin{array}{l}\text { Benign mixed mesenchymal stromal } \\
\text { tumour. }\end{array}$ & $\begin{array}{l}\text { SMA-positive, Calponin-positive, Ki67- } \\
\text { low index }\end{array}$ & Myoepithelioma \\
\hline
\end{tabular}

DFSP-Dermatofibrosarcoma protuberance, BFH-Benign fibrous histiocytoma 


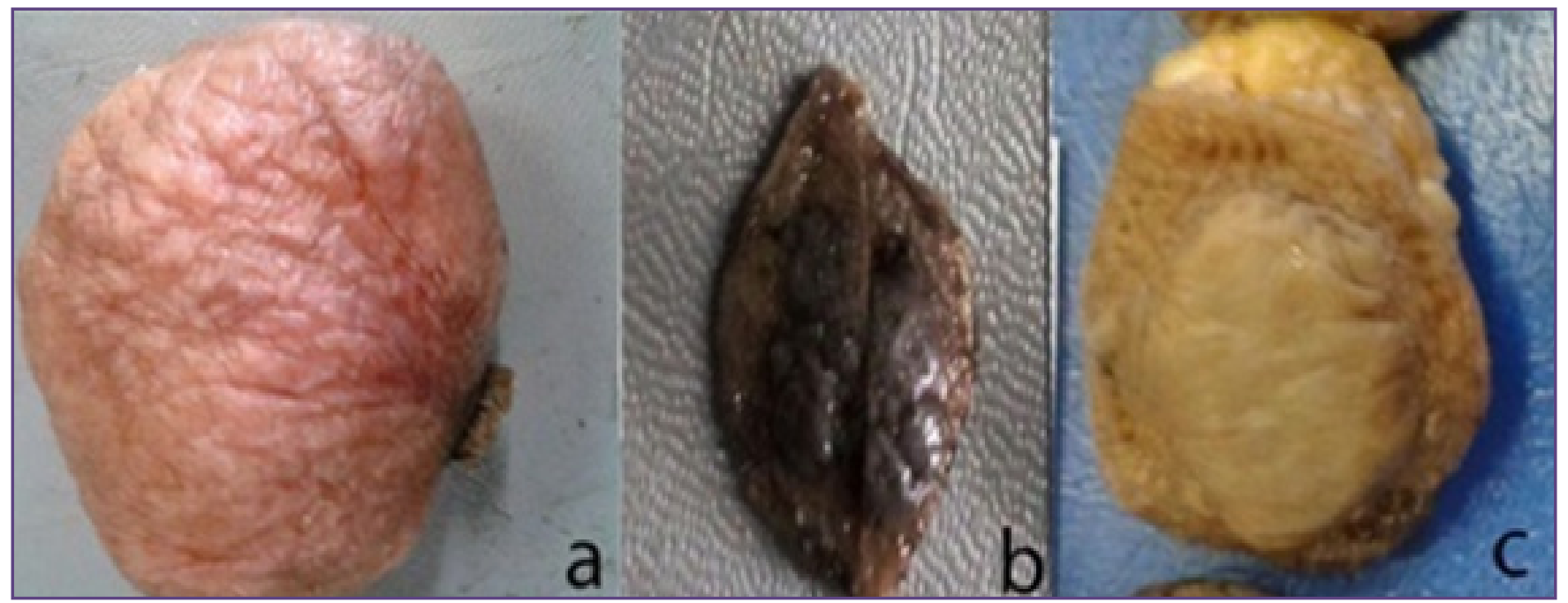

Fig. 1: Skin covered nodular growths with clinical diagnosis of ? lipoma? Haemangioma and histologic diagnosis of a) Lipoma b) Haemangioma c) Keloid.

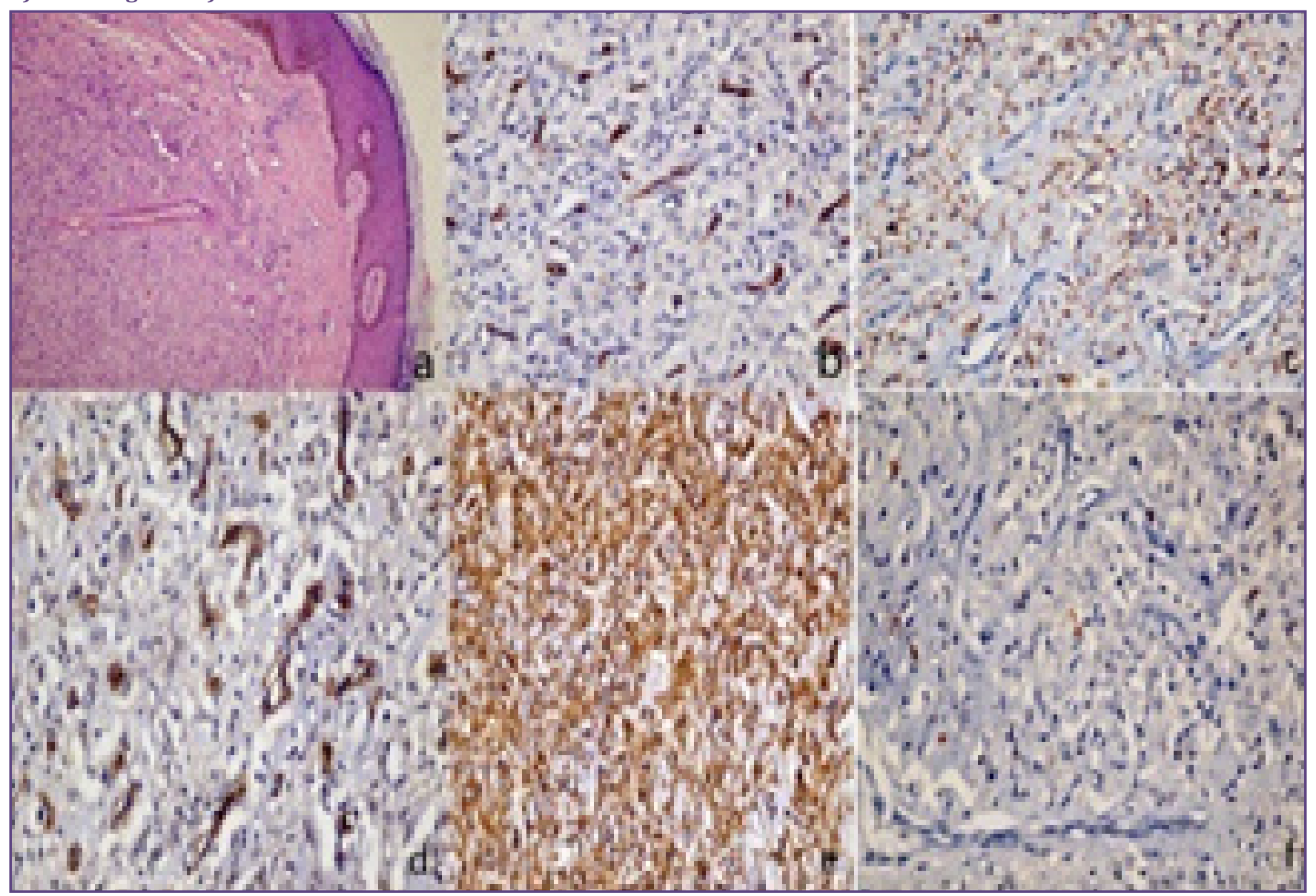

Fig. 2 : Benign fibrous histiocytoma ( H\&E,100X) composed of spindle cells with mild atypia and on light microscopy was thought to be atypical fibrous histiocytoma. IHC showed b) CD34 negative(400X),c) CD68 positive in histiocytes( 400X), SMA (d) \& Vim (e) positive in cytoplasm of spindle cells (400X) and f) low Ki 67 index(400X). 


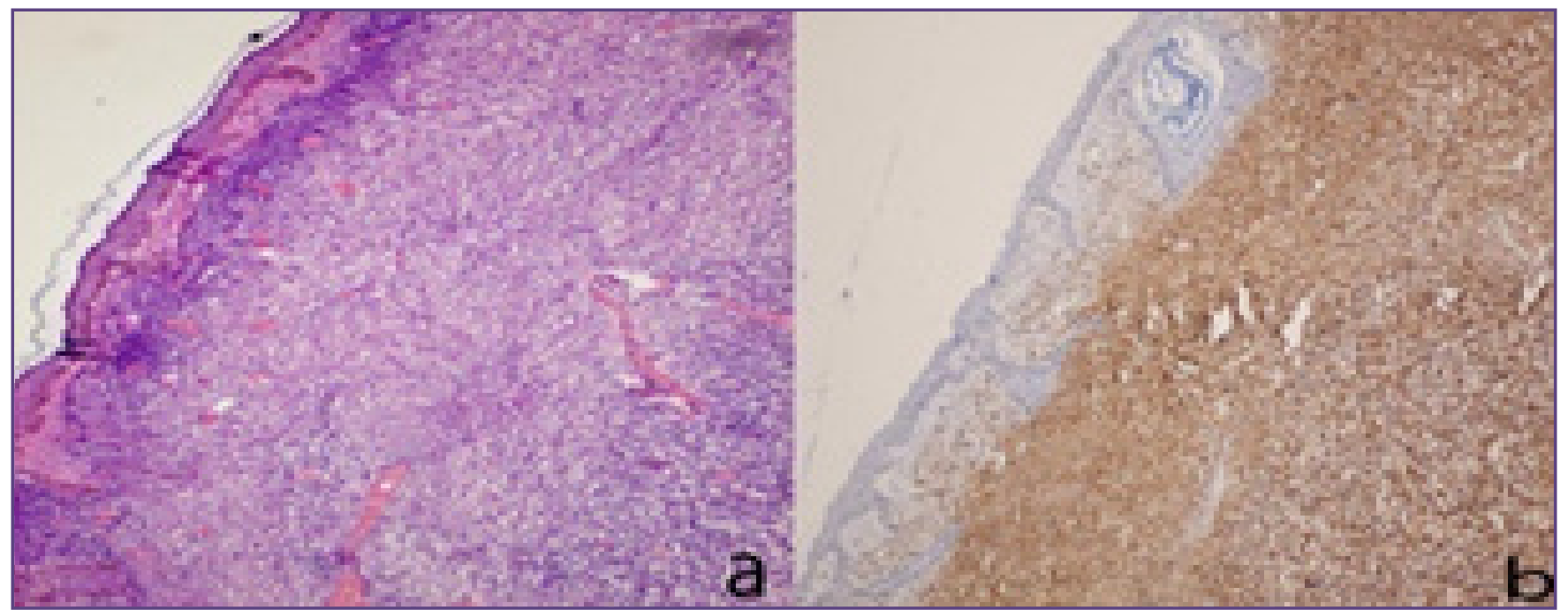

Fig. 3: a)Dermatofibrosarcoma Protuberans (100X): shows superficial dermis tumour with spindle cells arranged in storiform pattern. b) shows uniform strong positivitry for CD 34 in cytoplasm of spindle shaped tumour cells(400X).

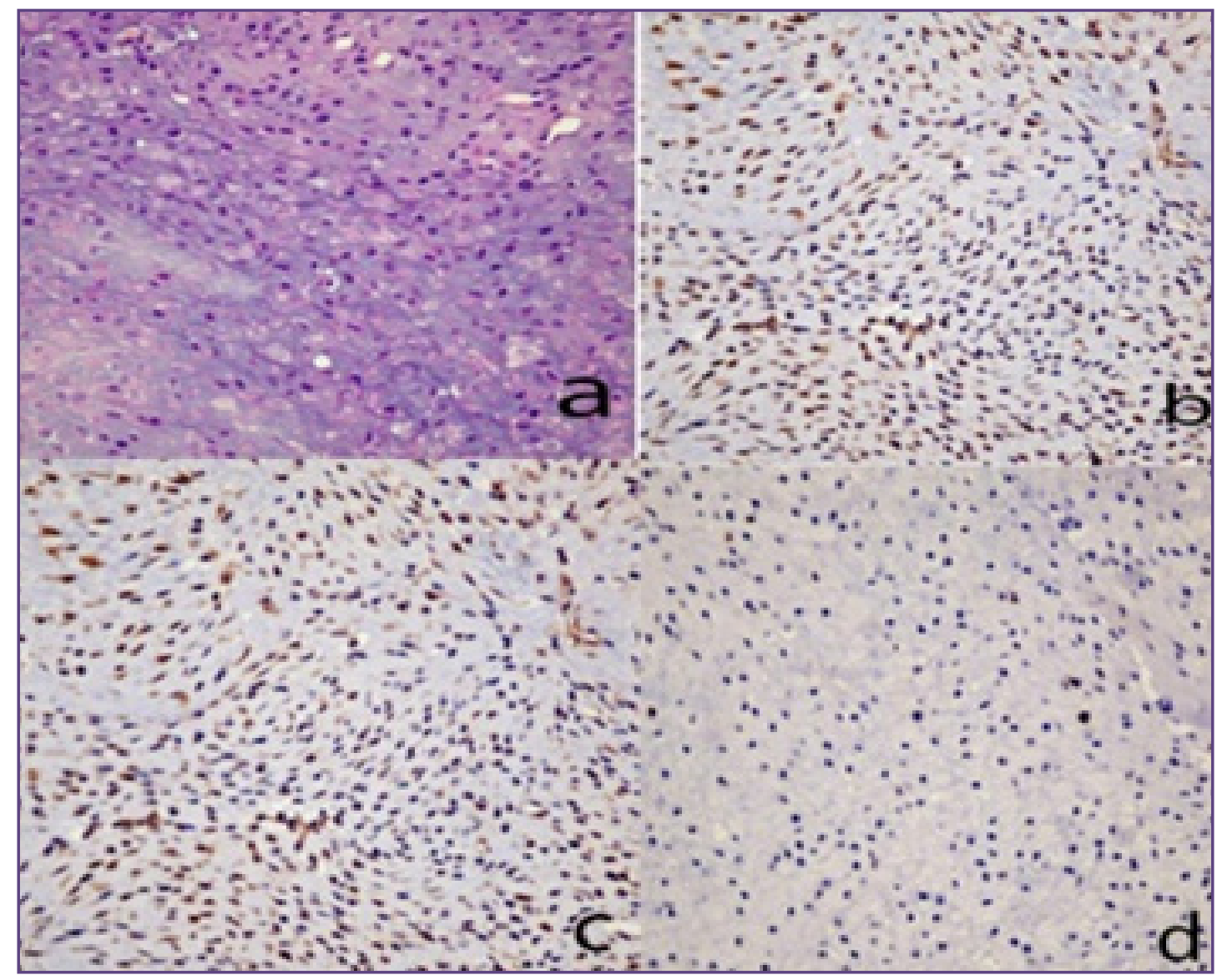

Fig. 4: a)Myoepithelioma(400X): composed of a mixed population of spindled, epithelioid, and plasmacytoid cells arranged around a central chondromyxoid stroma. Mild nuclear atypia (coarse chromatin and prominent nucleoli) was observed.b, c,d (400X): shows SMA positive, 


\section{Discussion}

Cutaneous soft tissue tumours, being heterogeneous group of mesenchymal and neural tumours are diagnostically challenging with constantly evolving histopathological criteria, immunohistochemistry and molecular genetics. ${ }^{[4]}$

The present study was undertaken to study clinical, morphological and demographic features of purely dermal cutaneous soft tissue tumours.

Adipocytic Tumours (36.9\%): Most frequent adipocytic tumour was lipoma (36.1\%), in the age group 20-30 years with higher incidence in men (M: $F$ ratio 1.7:1). Most common site was head and neck region. Majority of them were solitary, $<5 \mathrm{~cm}$ and presented with slow growth. All cases presented with painless growth and had typical gross picture of well circumscribed mass with yellow greasy cut surface and on histology showed lobules of mature adipocytes. Three variants, multiple lipoma, fibrolipoma and angiolipoma were noted. Lipoma usually is seen in 4060 years age group. Multiple lipomas are predominantly seen in upper half of body and in $5^{\text {th }}$ to $6^{\text {th }}$ decade and may show syndromic association. The single case of multiple lipomas was seen in 26 years old male, with lesions all over body. There was no syndromic association. ${ }^{[5,6]}$ Various studies ${ }^{[7,8,9,10,1]}$ have reported varying incidences of lipoma in their study population $78.7 \%, 16 \%, 26.4 \%, 40 \%$ and $37.9 \%$ respectively.

The variation in the incidence of lipoma in various study and present study can be attributed to the variation in the number of patients approaching the clinician. As increased incidence of lipoma is also claimed in obese than in slender persons, in diabetics and in those with elevated cholesterol, so variation in the incidence of lipoma in different populations can also be explained on the basis of varying incidences of these factors in the study populations. ${ }^{[12,13]}$ The variation in site distribution was also observed. Unlike this study, Kransdorf M J et al [7], Anders Rhydholm and Neil OB ${ }^{[10]}$ and Adair et al ${ }^{[13]}$ reported lipomas mainly on trunk and Jensen $\mathrm{O} \mathrm{M}$ et al reported on extremity ${ }^{[4]}$. This may be due to variation in the distribution of adipose tissue in various population. ${ }^{[9]}$

Liposarcomas are extremely rare in the skin. When they involve the skin, it is usually by upward spread from a subcutaneous or deeper seated liposarcoma. Very rarely, liposarcoma metastasize to the skin or arise as a primary dermal lesion. ALN/WDL liposarcoma is the most common form of liposarcoma encountered in late adult life. Those in the extremities develop as slowly growing masses. Grossly ALN/WDL is large multilobular lesions that range in colour from deep yellow to ivory. ${ }^{[2,5]}$ This study describes a case $(1.34 \%)$ of large multilobular gluteal mass in a 23 year old female since 5 years. Wide local excision mass was received. On histology it showed lipoblasts and atypical adipocytes. No IHC was performed.

Vascular Tumours (25.4\%): Only benign vascular tumors were encountered in this study. Haemangioma is most common cutaneous soft tissue tumors in paediatric and younger age group. In the present study it was second commonest tumor, in the age group 20-30 years and most common in paediatric age group. In paediatric age group it had typical presentation as slow, cystic growth in head and neck region, whereas in adults it presented in equal number of cases in extremities as lobular/nodular/warty/ fungating growth. Majority were painful and tender mass. Microscopy revealed predominantly capillary haemangioma. Haemangiomas are more frequently encountered in women ${ }^{[14,15]}$ Various studies ${ }^{[4,7,16]}$ had M: F as 1:3,1:2, 1:5 respectively, whereas in the present study male predilection was noted $(\mathrm{M}: \mathrm{F}=2.6: 1)$.

Perivascular Tumors $(\mathbf{0 . 8 \%})$ : Glomus tumour presented as a slow growing, tender painful and nodular growth of 3 years duration on the middle finger of a 40 year old male with classical histology. ${ }^{[2,15]}$

\section{Benign Fibrous Histiocytic Tumours (8.5\%):} Dermatofibroma (benign fibrous histiocytoma) (Figure-6) is a common skin lesion and it accounts for approximately $3 \%$ of the all skin lesions. ${ }^{[17]}$ In the present study it was the least common tumor and accounted for $6.7 \%$ of cases. Most common clinical presentation was of slow, nodular, well circumscribed growth in the upper extremity with no sex predilection. An elderly patient, 75 years male presented with swelling over the left shin which was solitary, slow growing, painless and a skin covered nodular mass, yellowish on cut surface. On light microscopy it revealed a well circumscribed tumour in the dermis composed of diffuse proliferation of spindle cells with fusiform nuclei and mild nuclear pleomorphism was seen. In view of spindle cells with mild atypia, diagnosis atypical fibrous histiocytoma was considered. Immunohistochemistry was carried out and the results were as follows: CD68Positive, SMA- negative, CD34- Negative, VimentinStrongly positive, Ki 67- Low index. Final diagnosis after immunohistochemistry was given as benign cutaneous fibrous histiocytoma sometimes can be mistaken for atypical fibrous histiocytoma. (fig.2)

A single case of atypical fibrous histiocytoma was observed in this study. It presented as a nodular, slow growth on the middle finger of a 50 year female. Atypical fibrous histiocytoma has been discussed by Bostjan Luzer and Eduardo Colonje in their review article published in 2010. ${ }^{[18]}$ Thomas Mentzel et al ${ }^{[19]}$ reported in their study published 
in 2013 that some morphological variants of cutaneous fibroushistiocytoma are clinically aggressive and show metastatic potential, like cellular, aneurysmal, aypical ( increased mitotic figures, large size, areas of necrosis) and show additional genomic aberrations as compared to conventional fibrous histiocytoma. Thus any variation from the usual should be reported and wide local excision with close follow up should be requested. Conventional $\mathrm{BFH}$ has better prognosis and rare recurrence rate than atypical fibrous histiocytoma or some of its variants.

A case of undifferentiated pleomorphic sarcoma was seen in a 55 year old male since 2 years as a multilobulated, large $10 \mathrm{~cm}$ fungating growth on left lower thigh. It increased in size rapidly.

Fibroblastic tumours (4.6\%):

All three categories of benign, intermediate and, malignant tumours were encountered with classical morphology. Fibroma was seen in a young female in axilla as a slow nodular growth with pain and tenderness. Of 3 DFSP 2 $(1 \mathrm{M}, 1 \mathrm{~F})$ presented as rapid growth in upper extremity with pain and tenderness in young adults. Female gave history of excision of similar tumour 5 years back. Third case was 71 years old male. All were positive for CD 34 and negative for S-100. (fig.3)

Benign Peripheral Nerve Sheath Tumors (23.1\%): Most common were neurofibromas, mean age 26 years, no gender predilection or site predilection seen. Majority were localized type with slow, nodular, painful and tender growth. Four had multiple growths of which one was plexiform type in an 11 year old male child. Schwannomas were seen predominantly in head and neck region with slow, nodular, painful and tender growth. Mean age was 46 years. All were solitary. Single case of MPNST occurred as a rapid, painful, tender and, solitary globular growth over right thigh of a 34 year old male.

In present study $70 \%$ tumours measured $1-3 \mathrm{~cm}$ in greatest dimensions and on cut surface showed whitish homogenous appearance. All revealed classical microscopy of neurofibroma ${ }^{[20]}$, schwannoma ${ }^{[2]}$ and, MPNST ${ }^{[21]}$.

Myoepithelioma (0.8\%): (fig.4) Of 147 cases of cutaneous soft tissue tumours only one case of myoepithelioma was observed. Twenty five year-old male who had solitary, painless mass over right middle finger, measuring $3 \mathrm{~cm}$ in greatest dimensions and light microscopy revealed a tumour composed of a mixed population of spindled, epithelioid, and plasmacytoid cells arranged around a central chondromyxoid stroma was noted. No definite diagnosis could be reached on this morphology and initial diagnosis of Benign mixed stromal tumour was considered. IHC (Figure-19-23) was performed that showed strong positivity for calponin, and SMA, weak and focal positivity for S-100, negative Pan CK and low $\mathrm{Ki}$ 67. The final diagnosis of benign myoepithelioma was entertained. Similar results were found in study of Hornick JL et al. ${ }^{[22]}$. They studied 101 cases of myoepithelioma. They observed equal gender distribution and peak incidence 30-50 years. According to their study painless mass was observed in $(28.7 \%)$ cases followed by painful mass $(16.4 \%)$. The majority of tumors arose in the limbs and limb girdles: $40.8 \%$ in the lower limb and $34.2 \%$ in upper limb, $14.8 \%$ tumors arose in the head and neck, and $9.8 \%$ on the trunk, $53.4 \%$ tumors were situated primarily in dermis. Macroscopic Features revealed tumor size ranged from 0.7 to $20 \mathrm{~cm}$ (mean $4.7 \mathrm{~cm})$.

\section{Conclusion}

Purely dermal cutaneous mesenchymal tumours are superficial and can be treated by wide local excision. Pathologists play an important role in reaching to accurate morphological diagnosis with the aid of IHC to prevent any uncertainty due to indistinct clinical features. This morphology based study will also help update the world wide literature on this subject.

\section{References}

1. Kügler D, Holzhausen HJ. Historical development of grading of malignant soft tissue tumors.Sudhoffs Arch. 2001;85(1):45-54.

2. Weiss S W \& Goldblum J R : Enzinger and Weiss's Soft Tissue Tumors, 5thed.Philedelphia: Mosby Elsevier;2008.

3. LeBoit P.E., Burg G., Weedon D, Sarasain A. (Eds.): World health organization classification of tumours. Pathology and Genetics of Skin Tumours. IARC Press: Lyon 2006

4. Jensen OM.A Consecutive 7-year series of 1331 benign soft tissue tumors. Clinicopathologic data comparison with sarcomas. Acta Orthop Scand. 1981; 52,:287-293

5. Brooks JSJ. Disorders of soft tissue. In: Mills SE editor Sternberg's diagnostic surgical pathology 5thed.Philadelphia: Lippincott William and Wilikins;2010.124-197.

6. Elder DE, Johnson B jr. Elentsas R. Lever's histopathology of the skin 9th ed. Philadelphia: Lippincott William and Wilikins;2005.

7. Kransdorf MJ.Benign soft tissue tumors in a large referral population. AJR 1995;169:395-405.

8. Rouhani P, Fletcher CDM, Devesa SS, Toro JR. Cutaneous soft tissue sarcoma incidence patterns in the U.S. An analysis of 12,114 cases. Cancer 2008;113:616-628.

9. Gibson TN, Hanchard B, Waugh N, McNaughtonD. A Fiftyyear Review of Soft Tissue Sarcomas in Jamaica: 19582007. West Indian Med J 2012; 61 (7): 692-697.

10. Rhydholm A, Berg NO. Size, site and clinical Incidence of Lipoma Factors in the differential diagnosis of lipoma and sarcoma. Acta Orthop Scand.1983; 54:929-934. 
11. Stout AP. Tumors of soft tissue. 5th ed. Washington D.C.St Louis Saunders Elsevier;1953.

12. Templeton, A. C. Soft tissue tumours. A Survey of Uganda 1964-68. Recent Results Cancer Res. 1973;41(8):234-269.

13. Adair FE, Pack GT, Farrior JH. Lipomas - A case study. Am J Cancer.1932; 16:1104-1120.

14. Goh SGN \& Calonje E. Cutaneous vascular tumours: an update. Histopathology 2008;52:661-673.

15. Kapuriya DP, Patel P, Shah AN. Histopathological study of 100 cases of vascular tumours. Nat J Med Res. 2012;2(2):152-155.

16. Harris MN,,Desai R,Chuang T-Y, Hood AF,Mirowski GW. Lobular capillary haemangiomas: An epidemiologic report, with emphasis on cutaneous lesions. J Am Acad Dermatol 2000;42:1012-1016.

17. Han TY, Chang HS, Kyung Lee JH, Lee WM,Son SJ. A clinical and histopathological study of 122 cases of dermatofibroma (Benign Fibrous Histiocytoma). Ann Dermatol. 2011;23(2):185-192.
18. Luzar B, Calonje E. Cutaneous fibrohistiocytic tumours -an update. Histopathology.2010;56:148-165.

19. Mentzel $\mathrm{T}$, Wiesner $\mathrm{T}$ et al. Malignant dermatofibroma: clinicopathological, immunohistochemical, and molecular analysis of seven cases. Modern pathology.2013;26:256-267.

20. Sharma S,Sarkar C, Mathur M,Dhinda AK, Roy S.Benign nerve sheath tumors. A light microscopic, electron microscopic and immunohistochemical study of 102 cases. Pathol. 1990;22:190-195.

21. Kar M,Deo SVS,Shukla NK,Malik A,Gupta SD,Mohanti $\mathrm{BK}$,et al. Malignant peripheral nerve sheath tumors (MPNST) - Clinicopathological study and treatment outcome of twenty-four cases. Wo J Surg Oncol. 2006; 4:55-62.

22. Hornick JL,Fletche CDM. Myoepithelial tumors of soft tissue a clinicopathologic and Immunohistochemical study of 101 cases with evaluation of prognostic parameters. Am J Surg Pathol. 2003Sept;27(9):1183-1196.

*Corresponding author:

Swati Vijay Patki, A-202, TILAK SHANTI CHS, TILAK NAGAR, MUMBAI(India)-400089

Phone: +91 8291026779

Email: drspkulkarni@yahoo.com

Financial or other Competing Interests: None. 